\title{
Production Sharing or Joint Venturing: What Is the Optimum Petroleum Contractual Arrangement for the Exploitation of Nigeria Oil and Gas?
}

\author{
SANI SAIDU*, HAMIDU ABUBAKAR SADIQ \\ Aberdeen Business School, Robert Gordon University, United Kingdom \\ *Corresponding author: S.SAIDU@RGU.AC.UK
}

Received May 25, 2014; Revised June 25, 2014; Accepted July 10, 2014

\begin{abstract}
Over time, stakeholders in the Nigerian oil and gas industry have been experimenting different contractual arrangement with the view of coming up with a best contractual arrangement for the industry. However, any shift from one contractual arrangement to another may affect the revenue generation position of the government and investments potentialities of the foreign oil companies. Similarly, the growing concern ranging from challenges of sustainability to transparency and accountability of transactions in the industry put the contractual arrangements on which the industry operates under question. Therefore, this study is aimed at finding out which among joint venture (JV) and production sharing contract (PSC) is optimal for exploitation of the Nigerian oil and gas industry in terms of economic rent, transparency and accountability derivable from the contract. Using contractual elements, pattern-matching and content analysis was used as the main techniques in analysing data. The results of the study have proved JV optimal in terms of economic rent, while PSC was found optimal in terms of accountability and transparency. On the overall, the results proved JV as optimal for the stakeholders in the Nigerian oil and gas industry. The study recommends government to place more emphasis on JVs in the industry, increase efforts towards fight against corruption in its agencies and officials, and increase the disclosure requirements of both its agencies and other operators in the industry particularly on those aspects of the processes that are more prone to corruption. Lastly, the FOCs operating in the industry should embrace and implement internationally acceptable good industry practices.
\end{abstract}

\section{Keywords: joint venture arrangement, production sharing contract}

Cite This Article: SANI SAIDU, and HAMIDU ABUBAKAR SADIQ, "Production Sharing or Joint Venturing: What Is the Optimum Petroleum Contractual Arrangement for the Exploitation of Nigeria Oil and Gas?” Journal of Business and Management Sciences, vol. 2, no. 2 (2014): 35-44. doi: 10.12691/jbms-2-2-2.

\section{Background of the Study}

Oil and gas exploration and development are characterised by huge capital expenditures, high technological expertise and the ability to manage investment risks. These factors, according to Bindemann (1999), are the drivers of exploration and development operations from geological surveys. Furthermore, oil and gas exploration, development and production operations have been a threat to the quality of life and hence, command expenditures on health, safety and environment. However, most oil rich developing countries lack the resources, technical expertise and capabilities to manage the large investment risks. As a result, Johnston (1994) opined that foreign oil companies (FOCs) with sufficient capital, expertise, and technology as well as investment risks capabilities are issued with licenses to explore and develop oil in the oil-rich developing countries.

Rights to explore oil are basically divided into two (Ponsgiri, 2004); concession licenses and contractual agreements. Concession was the first system of petroleum development arrangement originated from USA in 1859. Under concessions, FOCs have the control and ownership of oil and gas resources while the government receives revenues from rentals, royalties and taxes (Blake and Roberts, 2006). In contractual agreements, the government through National Oil Company (NOC) has the control and ownership of oil and gas resources but under contractual agreement it allows FOCs as contractors to finance and provide technical services for exploration and development operations (Johnston, 2003). Level of government participation, control granted to FOCs, compensation and reward-sharing formula are the main differences between concession and contract agreement (Johnston, 1994 and Bindemman, 1999).

Consequently, two major contractual arrangements emerge from the petroleum development rights, that is, joint venture arrangement (JV) and production sharing contracts (under contractual agreement). In joint venture arrangement, host government takes part in concessionary system as working interest owners, where a Joint Operating Agreement (JOA) is often drawn for the execution of the operations. The host government has 
indeed a predetermined ownership rates in the development and productions operation of the oil fields, and therefore, shares exploration, drilling and development expenditures (Brock et al., 2007). It also shares the benefits accruing from the operations as well.

In contrast, production sharing contract (PSC) arrangement is the common system of oil and gas contractual arrangement between government and foreign oil companies, in which the FOCs bear the exploration, drilling and development expenditures, the host government has the right to participate in the venture as a working interest owner at a predetermined rate (Brock et al. 2007). Under this system, FOC recover its share of exploration cost from future production, while the NOC is accountable of its own share of development and production costs (Pongsiri, 2004). Host government under PSC owns the concession as opposed to JV where the FOC owns a share of production for the services rendered (Johnston, 2003).

However, issues like economic rent derivable from contractual agreements, accountability and transparency of transactions in the oil and gas sector are becoming source of concerns to policy makers and the academic world. For example, Bindemann (1999) opined that maximising economic rent of players in the industry is the driving force behind shift from one contractual arrangement to another. Accountability and Transparency in the oil and gas sector are said to be responsible for misappropriation of oil revenues (Yumiseva, 2005) to poor governance, corruption, conflict and poverty. Similarly, oil and gas operations in the environmentally sensitive area (ESA) have led to different types of problems which include greenhouse emission, pollution and other social vices (Arscott, 2003; Miranda and Malik, 2008). Over a decade, the increasing recognition that improved transparency and accountability for the huge revenues generated by oil and gas industry is vital to avoiding the resource curse and extend the benefits of oil and gas resources abundance to poverty reduction (AFDB, 2007). As a result of this, different international policy initiatives, mechanisms and standards have been launched to address these problems, improve governance, and reduce the observed environmental and socioeconomic impacts of extractive industry activities. The prominent among them are; the extractive industries transparency initiative (EITI) and the international publish what you pay (PWYP) campaign.

EITI was launched in 2002 to address the general failure to transform resource wealth into sustainable development (the „resource curse“ or „paradox of plenty“) and the associated governance problems in the extractive industries sector (EITI, 2002). EITI principles focus on strengthening revenue accountability and transparency and environmental stewardship (Jordan, 2006). Though it is voluntary, EITI has recorded some significant achievements in solving the problems of corruption in oilrich developing countries (EITI, 2007; ADB, 2007b).

In a similar effort, the PWYP initiative is a global civil society organisation, aimed at promoting full transparency in the payment, receipt, and management of revenues paid to resource-rich developing country governments by the oil and gas industries. This is generally accepted as a significant effort towards a more accountable system for the management of natural resources revenues (ADB and AU, 2009). This disclosure as such, will strengthen the social standing of FOCs by demonstrating their positive contributions to society and hold governments accountable of the management of revenues. It is on this basis that this study wants to investigate which among the contractual agreements (PSC and JV) is more optimal. In sum the study wants to answer two major questions:

1. Which contractual arrangement among JV and PSC is optimal in terms of economic rent derivable in the Nigerian oil and gas industry?

2. Which contractual arrangement among JV and PSC is optimal in terms of accountability and transparency in the Nigerian oil and gas industry?

In order to address these questions, the paper has been divided into six sections. Accountability and transparency are the issues discussed in Section 2. Accountability and transparency implications with respect to JV and PSC are topics of concern in Sections 3 and 4. Section 5 briefed research designed employed in the study. Sections 6 and 7 discuss analyses of the study. In Sections 8, 9, 10 and 11 summaries, findings and conclusion of study are presented respectively.

\section{Accountability and Transparency}

Developing countries and economies in transition account for $94 \%$ of oil and gas reserves around the world. This together with their strategic role of exporting over $80 \%$ of world energy demand accorded them with huge revenues enough for economic growth and social development (McPherson, 2007). However, despite the substantial reasonable revenues from extractive industries of developing countries and economies in transition, the absence of accountability, of which transparency is an integral part, for these revenues encourage poor governance and leads to corruption, conflict and poverty. This view was also supported by Brackling (2009) where he states that, good governance and prudent management of the revenues generated from the oil and gas industry can foster growth, development, improve standard of living and reduce poverty.

Accountability according to Gray et al. (1996) "is the duty to provide an account (by no means necessarily a financial account) or reckoning of those actions for which one is held responsible”. Equally, Ebrahim (2003) said accountability is as a method by which those trusted with public resources promote the goals of their organisation, by allowing themselves to be questioned by the public on their actions. Arguing in similar direction Unerman and O’Dwyer (2006) consider accountability as a tool for holding managers of corporate entities accountable for the environmental, social and economic impact resulting from their organisational policies, practices and activities. Extending further to explain transparency, Goldwyn (2004) posits that transparency is a system that requires public officials to publish their revenues, expenditures and liabilities. Armstrong (2005) broadened the scope of transparency in public administration to mean unrestricted access to timely and reliable information on decisions and performance of public sector. Thus, McPherson (2007) stressed that having an effective accountability and transparency system in place, countries could create favourable investment climate, efficient management of resources and better poverty reduction policy. Prior 
studies established negative relationship between high natural resource dependence and economic growth rates (Robinson et al., 2006; Eigen, 2007; and Ocheje 2009). Their findings stem from the fact that in the oil and gas contractual arrangements, oil revenues payments always tend to be huge, occur through unclear means and result from crafty contract negotiations (Muhammad, 2011). This is consistent with Gallun and Wright (2005) that the actors in the petroleum industry intentionally clothed transactions in secrecy. It is in this regard that Auty (2004) concludes that huge revenue payments and the secrecy of the transactions in the industry decreases government willingness to diversity to other sections of the economy, thereby making it unaccountable to public. A coalition of civil society, governments, non-governmental organisations and companies come up with a multistakeholder voluntary principles of behaviour called the Extractive Industry Transparency Initiative (EITI), the major aim and objective of the scheme is to eliminate the problems of resource-curse by ensuring good governance through transparency and accountability in the management of resource rents (Kolstad and Wiig, 2008 and Ocheje, 2009). Nigeria has domesticated EITI and come-up with Nigeria Extractive Industry Transparency Initiative (NEITI) using the principles and criteria of EITI.

\section{Accountability and Transparency in Nigerian Joint Venture Arrangements}

Joint venture agreement in Nigeria has a clause that demands accountability by the operator to the nonoperator that is, the operator is required by the agreements to make available to the non-operator information and data in respect of joint operations, and joint accounts and such additional reports that they may require from time-to-time. This form of transparency and accountability exist between FOCs and the Nigeria National Petroleum Corporation (NNNPC) as co-venturers. Thus, there is element of transparency and mutual trust between the NNPC and FOCs. However, the closed relationship between NNPC and FOCs in JV arrangements and the way in which the contract is structured indicate that there is no provision to disclose information relating to joint operations to other groups of stakeholders of the Nigerian oil and gas industry (Nwokeji, 2007). Moreover, Ocheje (2009) sees confidentiality provisions of the JV agreements between government entities and producers in the industry stood in the way of disclosure of information by the government entities to relevant organs of government. Similarly, Oyefusi (2007) argues that the operation of JVs arrangements between Nigerian government and oil companies has done much to increasing incidence of oil crises in Nigeria, in addition to imposing huge financial responsibilities on the government, its operation has made oil companies in the country almost entirely involved in government administration. He adds that, reliance on Oil Company to operate community development programmes under the JVs a responsibility they are not suited to fulfil has made government to abandon their statutory responsibilities and has bred corruption and lack of transparency on the part of oil companies and government officials.
Consequently, some of the accountability and transparency challenges in JVs arrangement are reported by Igbanugo (2011), where he states that the combination of cultural, historical, economic and social factors in SubSahara Africa could affect the JV partner and lead to weak internal controls and accounting practices. It is also revealed that FOC may also feel commercial pressure to limit diligence to prevent finding itself at a competitive disadvantage. He supported this point with the Nigerian Bonny Island and TSKJ. TSKJ was a JV in Nigeria which comprises of four business entities; Technip, S. A., Snamprogetti Netherlands B.V., KBR (Kellogg Brown and Root, Inc.), and JGC. The four companies were formed in 1991 to construct LNG plants on Bonny Island, Nigeria. The JV was awarded four EPC contracts between 1995 and 2004. Before and during the award different financial irregularities occurred between the venture partners and NNPC. For instance, on September 3, 2008, KBR was found guilty of violating FCPA, for conspiring with and giving Nigerian officials bribe. In which the venture paid about $\$ 132$ million and $\$ 50$ million to different individuals as bribe before contract is awarded. The US Department of justice (DOJ) and the Securities and Exchange Commission (SEC) charged KBR up to $\$ 579$ million arising out of its FCPA anti-bribery charges. Similarly, Sanamprogetti Netherlands was charged with one count of conspiracy and one count of aiding and abating violations of the FCPA by DOJ and agreed to pay a sum of $\$ 240$ million criminal penalty to resolve charges related to participation in the Nigeria JV bribery. Other charges filed by SEC against Snamprogetti include falsifying books and records and circumventing internal controls. In the same JV, the DOJ charged Technip with one count of conspiracy and one count of violating the FCPA. Technip in effort to resolve the charges, on January 28, 2010 agreed to pay a sum of $\$ 240$ million criminal penalty. Lastly, JGC was also fined for violating FCPA by DOJ and agreed to pay a penalty charge of $\$ 218.8$ million. Ocheje (2009) attributed this corrupt acts and lack of transparency to the dual capacity of the NNPC as a JV partner and supervisor of the operations, where he states that "this sometimes bred conflict of interest without necessarily improving the contract awarding procedure or the joint ventures budget monitoring process”. Ocheje further explain this point with reference to NEITI audit report that, ....the equity streams of crude oil that flows to the NNPC from the JVs in which it participates, and to which NNPC has title under the terms of the joint operating agreement and that, the JVs account for some $75 \%$ of the total Nigerian crude production, there was no evidence of written and authorised procedures, nor was there documentary evidence of delegation of authorities there were conflicts in the contract procedure for the sale and purchase of crude and no written procedure for communication by NNPC personnel with price assessment agencies and there was a lack of record keeping of communication on market intelligent. Some of the fairly serious irregularities exposed by the report are; while cash calls would normally be expected to be contributed evenly over any given year at the end of 2004, there was a total of $\$ 933$ million held in NNPC transitory account of a total cash call of $\$ 4.3$ billion for that year. There was no explanation for this surplus. In addition, NEITI audit report reveals several inconsistencies and 
unresolved figures in respect of Royalties, PPT, cash calls and contributions to NDDC (Ocheje, 2009).

\section{Accountability and Transparency in Production Sharing Contract Arrangements}

In Nigeria, PSC arrangement require FOCs to furnish the NNPC with technical, financial and other information of any kind relating oil and gas operations, which to the public or any other third party is strictly confidential without a prior written consent of the other party (NNPC, 1993; 2000). This restricted the accountability and transparency of PSC transaction between NNPC and FOCs which is contrary to the principles of NEITI and PWYP, as transparency means openness of your business actions and activities to public scrutiny. Conclusively, in Nigeria, the issue of accountability and transparency is only applicable to contractors in relation to NNPC but none is responsible to make their affairs public. However, Ocheje (2006) reveals that according to the process audit report there was no recognizable model for production sharing contracts, and the quantity and quality of information available to the public were very low. The bidding process was all but transparent. He also adds that PSCs, running into hundreds of pages of complex legal and financial provisions which are generally subject to confidentiality, are known to lock host countries into arrangements for decades.

They generally exempt oil companies from any laws that might affect their profits, and they usually exclude domestic jurisdictions, favouring dispute resolution by international tribunals whose decisions privilege commercial rather than national interest considerations. This implies that PSCs are negotiated through nontransparent situations, which may negatively affect the country's take from the industry. According to the report some oil companies and government entities in Nigeria resisted the auditor's request for certain information by citing the need for confidentiality.

\section{Research Approach for the Study}

A case study methodology is adopted for this study, as the aim is to study the contractual phenomena (JVs and PSCs) of a specific industry (oil and gas) of a particular country (Nigeria). The study uses data on the relevant variables from the secondary sources, which include contractual agreements (JV and PSC), report of the NEITI, NNPC annual statistical bulletin, CBN annual economic reports, relevant journals, textbooks, presentations, newspapers, magazines and periodicals and industry related websites and Sustainability reports. Owing to the nature of data employed in this study, descriptive statistical tools are adopted in presenting collected data. The study employed patternmatching and content analysis techniques for data analysis.

\section{Data Presentation and Analysis}

As previous said, the determinants of our analyses are economic rent derive by the parties to contractual agreements and extent of accountability and transparency of activities within the Nigerian oil and gas industry. Thus, this section analyses these two issues accordingly.

\subsection{Economic Rent Utilisation}

Basically, the aim and objective of players in the oil and gas operations is to maximise their take of the associated rent from the production revenues generated by oil and gas contracts. The economic rents represent the proportion of revenues that government seeks to capture without altering the behaviour of investment (Onaiwu, 2007). The contractual elements that give rise to the maximisation of economic rent in the Nigerian oil and gas industry include; level of participation in the contract, financing operations by each party, royalties, cash calls, cost recovery oil, profit oil, PPT, bonuses and investment incentives and. These elements are analysed under JV and PSC to determine the optimal among them.

\subsection{Level of Participation in the Projects}

Under JVs, Nigerian government through NNPC has about $60 \%$ participator interest in all JVs agreements, on the other hand, FOCs have participatory interest of at least $40 \%$ stake in all the Nigerian JVS. While in PSCs government has no participatory interest at the exploration and development levels, and those FOCs borne all the costs and risks of the operations. Hence, government participation at exploration and development levels reduces costs and risks of exploration to both parties. However, government has a participatory right of 51 percent stake in PSCs on commercial discovery. Based on this, JVs appeared to be more optimal in the level of participation in the entire projects as this will affect the economic rent derivable from the contracts.

\subsection{Financing Operations by Each Party}

The agreements under Nigerian JV define the respective rights and duties of the parties, that is, NNPC and FOC in respect of limits of participating interest, control and management of the venture as well as costs elements of JV arrangements. Thus, the terms of the venture require Contribution of funds by each party to finance the operations to the extent of their respective interest in the operation. Therefore, in JVs both government and FOCs contribute funds to finance operations based on their participatory interests as this will reduce costs and risks of exploration to both parties. For example, the cash contributed by NNPC and FOCs in 2006, 2007 and 2008 indicate the level of participation by each party. Hence, the government cash call obligation paid to JV partners was $\$ 2.19$ billion and N206.33 billion in 2006, $\$ 2.62$ billion and N293.75 billion in 2007, and $\$ 2.51$ billion and N291.83 billion in 2008; these together with the share of JV partners are presented in Table 1. This findings support Kent and Hellriegel (1991) who argue for costs and risks of the oil and gas exploration and production.

However, in PSCs, FOCs bear all explorations and development costs, this is consistent with Atsebgua (1999) and Muhammed (2010). They document that exploration and development costs are borne 100 percent by the 
contractors, thus, bearing all the potential risks of the contracts. In line with this, JVs in which both parties contribute funds is considered optimal in terms of funds contribution.

Table 1. FUNDS CONTRIBUTION TO JVS BY GOVERNMENT AND JV COMPANIES

\begin{tabular}{|c|c|c|c|c|c|c|}
\hline \multirow{2}{*}{ Years } & \multicolumn{2}{|c|}{ NNPC } & \multicolumn{2}{c|}{ JV PARTNERS } & \multicolumn{2}{c|}{ TOTAL } \\
\cline { 2 - 7 } & \$'billion & N'billion & \$'billion & N'billion & \$'billion & N'billion \\
\hline 2006 & 2.19 & 206.33 & 2.41 & 192.56 & 4.59 & 398.89 \\
\hline 2007 & 2.62 & 293.75 & 1.69 & 183.13 & 4.32 & 476.88 \\
\hline 2008 & 2.51 & 291.83 & 2.59 & 287.17 & 5.11 & 579.01 \\
\hline
\end{tabular}

Source: NEITI 2011

\subsection{Payment of Royalties}

Royalties are the money received by the owner of a resource as compensation based on production volume irrespective of production costs and prices (Omorogbe, 2005). The comparison of production and royalties under Nigerian JVC and PSCs are presented in Table 2 and 3 respectively.

Table 2. CRUDE OIL PRODUCTION BY REGIME

\begin{tabular}{|c|c|c|}
\hline YEARS & JVS (BARRELS) & PSCS (BARRELS) \\
\hline 2007 & $462,888,989$ & $192,621,306$ \\
\hline 2008 & $471,900,351$ & $195,127,693$ \\
\hline 2009 & $331,554,144$ & $268,792,256$ \\
\hline 2010 & $364,717,172$ & $316,887,117$ \\
\hline 2011 & $348,509,885$ & $289,333,720$ \\
\hline \multicolumn{2}{|c}{ Source: NNPC (2011) }
\end{tabular}

The royalties paid are based on production and are a function of water depth, they decrease as water depth increases.

Table 3. ROYALTIES PAYABLE ON OFFSHORE PRODUCTION

\begin{tabular}{|c|c|}
\hline AREA IN MATERS & RATE \\
\hline $0-100$ m depth & $18.5 \%$ \\
\hline $100-200$ m depth & $16.5 \%$ \\
\hline $201-500$ m depth & $12.0 \%$ \\
\hline $501-800$ m depth & $8.0 \%$ \\
\hline $801-1000 \mathrm{~m}$ depth & $8.0 \%$ \\
\hline Over 1000 m depth & $8.0 \%$ \\
\hline
\end{tabular}

As shown in Table 2 above, JVs have the highest volume of production over the periods of the analysis, implying maximising revenues to both the government and the FOCs, in the sense that they are based on production. Hence, this increases the economic rent. In addition, prior to 2005 there was no royalties in respect of water depth in excess of 1000 meters; almost all the Nigerian PSC fields are beyond 1000 meters water depth. It can be said that PSCs deprived government royalties. This finding supports the findings of Umar (2005) and Muhammad (2010). Moreover, under Nigerian JVs contracts there is royalties of 20 percent on all onshore oil and 7 percent on gas projects in addition to offshore royalty rate shown in Table 3 . Inland basin PSCs are subject to 10 percent royalties. Therefore, JVs are optimal in terms of revenue generation through royalties.

\subsection{Cost Recovery}

Prior to 2005, Nigerian PSCs allow FOCs to recover all operating and capital expenditures, but from 2005 FOCs are only allowed to recover $80 \%$ of the costs. However, operators under the JVs recover their cost from share of oil allocated to them. Based on this evidence, JVs appeared to be optimal with regards to cost recoverability because both government and FOCs share the exploration and production costs using their participatory interest.

\subsection{Profit Oil}

In PSC, profit oil is shared between FOCs and government after cost recovery oil is removed, based on an agreed rate. Such provision is not obtained in JVs and thus, it can be inferred that PSC is optimal in this respect as this will affect the economic rent. The current profit oil under 2005 PSC as indicated in Table 4 is based on the sliding R-factor scale; in which NNPC receive minimum of $30 \%$ (maximum $75 \%$ ) and FOCs minimum of 25 (maximum 70\%).

Table 4. PROFIT OIL SPLIT UNDER 2005 PSC MODEL

\begin{tabular}{|c|c|c|}
\hline R-FACTOR & CONTRACTOR SHARE & $\begin{array}{c}\text { GOVERNMENT } \\
\text { SHARE }\end{array}$ \\
\hline $\mathrm{R}<1.2$ & $\mathrm{P}=70 \%$ & $100 \%-\mathrm{P}$ \\
\hline $1.2<\mathrm{R}<2.5$ & 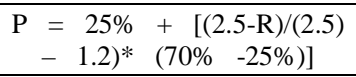 & $100 \%-\mathrm{P}$ \\
\hline $\mathrm{R}>2.5$ & $P=25 \%$ & $100 \%-\mathrm{P}$ \\
\hline
\end{tabular}

Source: Adapted from Onaiwu, 2007

\subsection{Income $T a x$}

While Nigerian JVs are subject to a standard PPT of $85 \%$ after the initial rate of $65.75 \%$ applicable until a company has recovered pre-production costs, PSCs are liable to PPT at flat rate of 50 percent. Therefore, JVs appeared to be optimal.

\subsection{Bonuses}

Nigerian PSCs features signature and production bonuses from about \$1 million for early 1990s PSCs, \$200 million for 1999 PSCs and \$30 million for post 2000 PSCs. The signature bonuses received by Federal Government of Nigeria are \$127.69 million in 2005, $\$ 720.74$ million in 2006, \$383.39 million in 2007 and $\$ 30.05$ million in 2008. This improved the revenue generated by the government from the PSCs and as such, it can be inferred that PSC is optimal.

\subsection{Investment Incentives}

To encourage investments and maintain cost efficiency, a tax inversion rate of 35 percent shall be applied under 
Nigerian JVs. Similarly, there is a guaranteed minimum notional margin of \$2.50, and \$1.25 for FOCs and NNPC premised on national fiscal technical cost of $\$ 4.0$ per barrel or \$2.70 and \$1.35 per barrel for FOCs and NNPC when the company's actual capital investment costs exceeds \$2.00 per barrel on average. While PSCs" investments incentives basically is investment tax credit or investment tax allowances (ITA) of $50 \%$ on any qualifying expenditure incurred. From the above evidence, JVs appeared to be optimal in that the guaranteed nominal profit margin given to FOC is an assurance to FOCs as investors that at any given operational circumstances, they will not operate at loss. Moreover, 35\% tax inversion will enhance FOCs earnings and attracts further investments into the Nigerian oil and gas sector. This finding supports the findings of Gidado (1999) and Muhammad (2010) and contradict the findings of Atsegbua (1999).

\section{Accountability and Transparency}

The NEITI 2006-2008 reconciliation report found different difficulties and system weaknesses in the Nigerian oil and gas industry which stem from lack of accountability and transparency in the transactions between the parties involved and the general public. The major areas that transparency and accountability was found wanting according to the report are in respect of the collection, accounting, receipts and remittance of PPT, Royalties, cash calls and signature bonuses. Therefore, in this section, the analysis of these elements with reference to financial, physical and process audit is presented using the JVs and PSCs arrangements.

\subsection{Payment of Petroleum Profit Tax}

The audit report reveals that the confidentiality clause of the JVs arrangements between government entities and the FOCs in the industry hindered the disclosure of information by the operators in the industry to relevant organs of government and the general public. For instance, according to Ocheje (2006) the amount reflected in PPT account of the CBN was more than what the oil companies had paid in 2003 and 2004. One of the noticeable transactions in this regard was the Chevron Nigeria limited JV in 2003, where the amount of PPT paid by Chevron was $\$ 471$ million which is reflected as $\$ 518$ million in CBN accounts. The same incidence occurred in 2004 where CBN recorded \$ 23 million as against \$ 9 million PPT from Chevron. Furthermore, the report documented a lot of problems with the collection of PPT from upstream operators in which PSC is the dominant arrangement. Upstream operators according to report submitted low monthly estimates of the PPT owed without prompt reconciliation of their estimates with actual production figures. The PPT flows arising from the oil and gas operations as reported initially by the government and the companies together with the adjusted figures and unresolved differences are presented in Table 5.

Table 5. PPT PAYMENT BY JV COMPANIES

\begin{tabular}{|c|c|c|c|c|}
\hline YEARS & \multicolumn{2}{|c|}{ INITIAL FIGURES } & DIFFERENCES & ADJUSTED FIGURES \\
\hline & Gov't \$"000 & JV Companies \$"000 & $\$$ \$"000 & $10,022,955$ \\
\hline 2006 & $9,775,427$ & $8,784,861$ & 990,566 & $7,250,050$ \\
\hline 2007 & $7,105,070$ & $7,798,048$ & $-692,978$ & $10,189,223$ \\
\hline 2008 & $8,298,906$ & $9,063,000$ & $-764,094$ & \\
\hline
\end{tabular}

Source: NEITI 2006-2008 Audit Report

Therefore, based on the table above, there are lack accountability and transparency in the payment and receipts of PPT by JV companies. According to the report, while in 2006 government reported PPT of $\$ 9.78$ billion the JV companies reported $\$ 8.78$ billion resulting in the difference of \$9.91million. However, the audit program discovered $\$ 10.02$ billion as the actual PPT due to the companies. Similarly, in 2007, the auditors discovered $\$ 7.25$ billion as the actual amount of PPT due to the companies, while the initial figures reported by the government was $\$ 7.11$ billion and the companies indicated more than what government reported ( $\$ 7.79$ billion) with the difference of $\$ 6.93$ million. The same thing occurred in 2008 the initial amount reported by the government and the JV companies show a difference of \$7.64 million, after the adjustments and reconciliation the auditors found that the actual amount of PPT was $\$ 10.18$ billion for the year as against $\$ 8.29$ billion and $\$ 9.06$ billion as reported by government and Companies respectively. These imply a great deal of lack of transparency and accountability that originated from the closed arrangements and flow of cash between FOCs and the government. However, the audit program did not report such cases with respect to PSCs as this analysis collected disaggregated data from the report. Thus, from these evidences, PSCs are optimal in terms of transparency and accountability, because in PSCs FOCs are $100 \%$ responsible for all the costs and risks, and that the PPT charge is based on the reported production.

This finding is in line with Oyefusi (2007) who documented that the operations of JVs arrangements between Nigeria and oil companies which impose huge financial responsibilities on government bred corruption and lack of transparency on the part of oil companies and the government officials. It is also consistent with Igbanugo (2011) who reported lack of accountability and transparency as the major challenge in JVs arrangement by supporting his point with the TSKJ $\mathrm{JV}$ in the Nigerian Bony Islands projects in which the US Department of Justice charged all the FOCs for conspiring with and giving Nigerian officials bribe of $\$ 132$ million and \$50 million to different individuals, in respect of Bony Island bid. Moreover, the report reported the difficulties by the impact of the MOU which covers the provisions of JVs on PPT assessment and payment; this is consistent with Ocheje (2006), who states that MOU contained a very complex formula that was not easily understood by a majority of stakeholders in the industry. This according to the report inhibits transparency and defeats verification and accountability of PPT assessment.

\subsection{Payment of Royalties}


The physical audit report discovered undesirable ways in which oil companies accounted for oil and hence royalties. According to the report, the information presented by the companies was unreliable and did not help to establish the amount of unaccounted oil. Consequently, the aggregation of net and gross balances gave a misleading picture of the relationship between the figures supplied by the JV companies. The comparison between the reconciled physical hydrocarbon balance and the declared volumes for royalty purposes revealed differences as indicated by Table 6 below:

Table 6. ROYALTIES PAYMENT BY JV COMPANIES

\begin{tabular}{|c|c|c|c|c|}
\hline YEARS & \multicolumn{2}{|c|}{ INITIAL FIGURES } & DIFFERENCES & ADJUSTED FIGURES \\
\hline & Government \$"000 & JV Companies \$"000 & \$"000 \\
\hline 2006 & $3,776,881$ & $3,780,297$ & $-3,416$ & $3,697,606$ \\
\hline 2007 & $3,809,490$ & $3,801,493$ & 3,995 & $-14,358$ \\
\hline 2008 & $4,738,738$ & $4,753,096$ & $4,864,061$ \\
\hline
\end{tabular}

Source: NEITI, 2006-2008 Audit Report

From the table above, there is lack of accountability in the operations of JVs arrangements in the determination and payment of royalties. For instance, in 2006, the companies claimed that they paid royalties of $\$ 3.78$ billion and the government reported the royalties of $\$ 3.77$ billion while the report found that the actual royalties" payable was $\$ 3.69$ billion with the difference of $\$ 3.42$ million. Similarly, in 2007 the report revealed a difference of $\$ 7.99$ million between the amount reported by the government and the JV companies, after the adjustments the report found that the actual amount of royalties for the year was \$3.73 billion. Still the trend persists in 2008 where the auditors reported a difference of \$14.36 million from what the government and the JV companies reported as royalties for the year. None was found in respect PSC arrangements by the auditors and as such this study consider PSC optional in terms of royalty's payment. This finding is consistent with the finding of Ocheje (2006) and Charles (2008) who documents that there are no transparent procedures in the collection and remittance of money from FOCs to NNPC and CBN. In addition, the audit report emphasizes this finding with the unresolved differences despite the verifications, reconciliations and adjustments made which some companies have not provided explanations for the differences.

\subsection{Signature Bonuses}

As contained in the provisions of the oil and gas contractual arrangement, signature bonuses are restricted to PSCs. According to the physical, process and the financial audit report, signature bonuses are the responsibility of DPR who in collaboration with OAGF monitors their receipt. The comparison of the initial receipt by the OAGF and DPR and the payment made by the companies is presented in Table 7 as follows;

Table 7. SIGNATURE BONUSES PAID BY PSC COMPANIES
\begin{tabular}{|c|c|c|c|}
\hline YEARS & $\begin{array}{c}\text { COMPANIES } \\
\mathbf{\$} \mathbf{0 0 0}\end{array}$ & $\begin{array}{c}\text { OAGF/DPR } \\
\mathbf{\$} \mathbf{0 0 0}\end{array}$ & $\begin{array}{c}\text { UNRESOLVED } \\
\text { DIFFERENCES \$000 }\end{array}$ \\
\hline 2005 & 127,695 & 150,138 & 22,443 \\
\hline 2006 & 720,741 & 985,100 & 264,359 \\
\hline 2007 & 383,396 & 509,849 & 127,107 \\
\hline 2008 & 30,051 & 180,051 & 150,000 \\
\hline
\end{tabular}

Source: NEITI 2006-2008 Audit Report.

From the unresolved differences in Table 7, there is clear evidence that signature bonuses are an avenue for financial misappropriation and irregularities. Based on this it can be inferred that there is lack of transparent and accountable dealing in PSCs with respect to signature bonuses. Thus, JVs are considered optimal in this regard. This finding is consistent with Abutudu and Garuba (2011) who reported that it is in the context of PSCs that the Nigerian government demanded its unpaid signature bonuses running in to billions of dollars since 1999. He quoted "Reps ask firms to pay N225.45 trillion; FG demands \$231 million signature bonuses form Korean firm for two oil blocks; $65 \%$ of signature bonus remains unaccounted".

\subsection{Cash Call Payment}

Cash call as the financial obligation to the JV partners and the government has suffered some from inconsistencies of accountability nature, because the report found that there was under payment by both government and JV partners totalled \$782 million and N52.9 million in 2006, \$809 million and N79.7 in 2007 and \$481 million and N57.0 million in 2008 as contained in Table 8.

Table 8. CASH CALL UNDERPAYMENT BY GOVERNMENT AND JV PARTNERS

\begin{tabular}{|c|c|c|c|c|c|c|}
\hline \multirow{2}{*}{ Years } & \multicolumn{2}{|c|}{ NNPC/NAPIMPS } & \multicolumn{2}{c|}{ JV PARTNERS } & \multicolumn{2}{c|}{ TOTAL } \\
\cline { 2 - 7 } & $\$ \prime 000$ & N'000 & $\$ \prime 000$ & N'000 & $\$$ \$000 & N'000 \\
\hline 2006 & 716,041 & $48,979,592$ & 66,455 & $3,989,956$ & 782,496 & $52,929,548$ \\
\hline 2007 & 554,793 & $55,656,671$ & 253,990 & $24,113,925$ & 808,783 & $79,770,596$ \\
\hline 2008 & 461,050 & $50,518,414$ & 19,592 & $6,506,684$ & 480,642 & $57,025,098$ \\
\hline
\end{tabular}

Source: NEITI 2006-2008 Audit Report

The table also shows the disaggregated data with respect to government and the JV partners. From these evidences, the study considers PSCs as optimal. 
Oil and gas exploration activities in Nigeria attained commercial quantity in 1956, following this development, a good number of FOCs joined the Nigerian petroleum industry in 1965. This expansion in the industry made Nigerian government to exercise control over its petroleum resources and began to search for the optimal contractual arrangement after joining OPEC in 1971. It follows that, Nigeria came up with a JV contractual arrangement in 1969 replacing traditional concession. Similarly, PSC began in 1973 as a result of emergence of offshore oil and gas operations. Lastly, RSC was entered into by the government in 1979 with some FOCs. These changes from one contractual arrangement to another in the industry can be regarded as a search for the optimal contractual arrangement for the stakeholders. Thus, this constitutes the problem of this study. Therefore, the main aim of this study was to determine which among JV and PSC is the optimum petroleum contractual arrangement for exploitation of Nigerian oil and gas reserves. The research evaluated this in terms of economic rent, transparency and accountability. This study is significant in highlighting the optimality of one of the two major contractual arrangements in terms of economic rent, accountability and transparency to in the Nigerian petroleum industry. Also, the growing needs of foreign direct investment without endangering Nigerian interest by reconciling FOCs need of profit maximisation with the Nigerian government requirements of sustainable development, fighting corruption and bribery in the petroleum industry, and essentially the importance of the oil and gas sector to the Nigerian economy as the main source of revenue generation makes this study critical. Joint ventures in the oil and gas contractual arrangement is a modern form of concession whereby host government through its NOC participate in the venture and a JOA is drawn for the prosecution of the venture. JOA is a constitution that governs the JV which comprises of a joint right to control and a sharing formula for profits and losses. Economies of scale finance and technological risks are the motives behind JVs in the oil and gas industry. Nigeria is receiving a share in oil and gas production and the proceeds from the sales of petroleum resources as well as taxes from JV arrangements, thereby maximising the economic rent and enhances the economic growth and development of Nigeria. However, transfer of technology is increasing and unbearable and also cash call obligations associated with JVs arrangement termination of contract is at no cost to government if no oil is found and proportionate sharing of all expenses and profit if no oil is found are some of the major constraints and reasons of engaging into PSC in Nigeria. PSC is a contractual agreement between FOC and host government in which the contractor (FOC) bears all exploration costs, risks and development production costs in return for a specific share of the production from the operations, sharing of production according is the heart and goal of PSC. The common features that differentiate PSC from other types of contractual arrangements are: entire exploration risks are borne by FOCs and receive no compensation if no oil is found and the host governments have the ownership of both the resources and installations.

\section{Discussion of Findings and Policy Implication}

In this section, the findings from the data presented and analyzed in the previous sections are presented and discussed in relation to the contractual elements used in the analysis.

\subsection{Economic Rent}

1. In terms of participatory interest, this study found that JVs are optimal in that they accorded both government and FOCs with optimal participatory interest in the oil and gas exploration, development and production in the industry. Out of the six existing JVs government has 60 percent take in $5 \mathrm{JVs}$ and 55 percent in one JV, while FOCs have 45 percent in one and 40 percent in four JVs. On the other hand, the study found that government has no participatory interest in PSC, but upon commercial discovery. This has the implication of slowing the face of technology transfer that would speed up NNPC to operate independently.

2. This research found that JVs optimal by provide both government and FOCs the optimal framework of funding contracts/operations. In JVs agreement, oil and gas operations funds are contributed by JV partners in proportion to their participating interests. While under PSCs, FOCs bear all the risks and costs of exploration and production. Though government participates on commercial discovery. The implication here is that, government may not have required control over the mineral resources due to lack of financial commitment to the operations.

3. Joint Ventures are also found by this research as the optimal contractual agreement in the industry on payment of royalties for both government and FOCs. There are a flat rate of $20 \%$ royalties for onshore oil and $7 \%$ for onshore gas under JVs. While offshore royalties are paid on a graduated scale with zero percent royalties for water depth beyond 1000 metres. Under pre-2005 PSC the royalty on water depth beyond 1000 metres is zero, since most of the PSCs are mostly beyond 1000 metres, government does not have any revenue from them. This has the implication of reducing government revenue from royalties.

4. This study found JVs contractual arrangement as the optimal for the exploitation of the stakeholders in the industry in terms of cost recoverability. Under JVs, both government and other JV partners contribute fund according to their participatory interest to finance the costs of exploration and production thereby living all the partners at equilibrium. In contrast, in PSCs arrangement, FOCs are only allowed to recover 80 percent of their costs of explorations and production on commercial discovery. This may result in gold plating of contract costs. The policy implication in this situation is that government may be losing resources on wasteful expenditures by FOCs.

5. On profit oil, this research found PSCs optimal in providing the government and FOCs equitable share of the oil left after cost oil and royalty oil. The share of profit oil which is currently on sliding R-factor gives government profit oil; minimum 30\% and 75\% maximum, while FOCs minimum $25 \%$ and $70 \%$ maximum. However, under JVs both the government and JV partners have no provisions for profit oil.

6. On income tax, JVs are found optimal in terms of PPT by making it flexible. The initial rate of $65.75 \%$ is 
applicable until a company has recovered pre-production costs and thereafter $85 \%$. While in PSCs FOCs are liable to $50 \%$ flat rate of PPT. The policy implication of this is that it will not attract more investment into the industry.

7. This research found PSCs arrangement optimal through bonuses, as generating more revenue to the government and giving FOCs room to exploit natural resources in Nigeria. This is not found under JVs contractual arrangement, as the platform of JVs is royalty tax system.

8. On investment incentives, this research found JVs contractual arrangement optimal to government and the FOCs. JV agreements have offered a guaranteed minimum national margin which changes with prevailing costs and prices of oil and tax inversion rate of $35 \%$. On the contrary, PSC agreement has not offered investment incentives needed rather put a non-cap on cost recoverability.

\subsection{Accountability and Transparency}

1. This study found PSCs transparent in the assessment, payment, and the collection of PPT. This is because the EITI audit programme did not report any problem with companies under PSC arrangements with respect to the assessment, collection and payment of PPT. However, most of the companies under JVs are found with the cases of conflicting differences between what they reported and what government recorded as PPT in their account. Moreover, the adjustment and reconciliation of the figures reported by the government and FOCs produced an entirely different figure. The policy implication of this finding is that it will increase the potentials of committing fraud and embezzlement of government funds by the officials involved.

2. On payment of royalties, PSCs are also found optimal because of the information they provided are free from material misstatement and errors. Thus, complete and in agreement with the actual royalties payable. In contrast, JVs are found with differences in the record of royalties paid to the government and the adjusted figures by the auditors. This has the implication of reducing government revenue and promoting corrupt acts and increasing poverty.

3. This study found JV arrangements as optimal in that under the agreements no issue of bonuses which serve as a germinating soil for misstatements and misconducts by the parties and entities involved. The study discovered discrepancies in the amount of signature bonuses claimed by the government and the companies and also with the amount adjusted by the auditors.

4. The study also discovered inconsistencies in the payment of cash calls by the JV partners. The report of the auditors indicated discrepancies among the amount of cash calls paid by the parties and the underpayment made by the JV partners. As such, PSC is considered optimal because there is no such issue of cash call in the agreement as the FOCs bear all the costs.

5. On contributions to NDDC, this study found that there is no transparent arrangement among the JVs and PSCs due to the discrepancies and unresolved difference, discovered between the amount claimed by the companies and the amount reported by the government and the adjusted figures by the auditors.

\section{Research Question: Restated and Answered}

(1) Which contractual arrangement among JV and PSC is optimal in terms of economic rent derivable in the Nigerian oil and gas industry? Based on the result of the data analysed on eight contractual elements for economic rent JV proved optimal in terms of economic rent derivable from the contract with 75 per cent optimality.

(2) Which contractual arrangement among JV and PSC is optimal in terms of accountability and transparency in the Nigerian oil and gas industry? From the evidences gathered on five contractual elements PSC proved optimal in terms of accountability and transparency.

\section{Conclusion}

Based on the relevant data collected and analysed in this study and the comprehensive study of the contractual arrangements with respect to economic rent and transparency and accountability, this study conclude that JVs contractual arrangement has proved to be the optimal for the exploitation in the Nigerian petroleum industry with 71.43 per cent optimality JVs accorded both government and FOCs with optimal participatory interest in the oil and gas exploration, development and production in the industry and providing both government and FOCs the optimal framework of funding contracts/operations. In that the oil and gas operations funds are contributed by JV partners in proportion to their participating interests. The study also documented JVs as optimal with regards sustainable development, through contribution to environmental, social and economic sustainability in Nigeria. Lastly, the study found PSCs as more transparent arrangement in the industry.

\section{References}

[1] ABDULKARIM, R. 2009. The Fiscal Tools in the UK Petroleum Licensing: How did the UK Attract Investments and What are the Effects of Changing Terms? The Centre for Energy, Petroleum and Mineral Law and Policy Annual Review. June 2009. pp.24.

[2] ABUTUDU, M. And GARUBA, D. 2011. Natural resources governance and EITI implementation in Nigeria. Current African issues 47.

[3] ARMSTRONG, E. 2005. Integrity, Transparency and Accountability in Public Administration: Recent Trends, Regional and International Developments and Energy Issues. Economic and Social Affairs.

[4] ARSCOTT, L., 2003. "Sustainable Development in the Oil and Gas Industry”. HSE Horizons, Exploration and Production Environmental Conference, Texas: San Antonio.

[5] ATSEGBUA, L. 1999. The Development and Acquisition of Oil Licenses in Nigeria. OPEC Review. pp. 55-77.

[6] AFRICA DEVELOPMENT BANK, 2007. African Development Bank Memorandum on EITI-Support to Implementation of EITI in Resource Rich Regional Member countries. AFDB/AD Fund, Tunis.

[7] AMEH, O. A., 2006. The Shift from Joint Operating Agreement to Production Sharing Contracts in the Nigerian Oil Industry: Any Benefits for the Players? CEPML Annual Review.

[8] AUTY, R.M. 2004. "Economic and Political Reform of Distorted Oil-Exporting Economies”: Managing Natural Resource Revenues in Low-Income Countries. A Paper Presented at the Conference on Escaping the Resource Curse. 26 February 2004. New York. Centeron Globalization and Sustainable Development. University of Columbia. 
[9] BLAKE, A. J. and ROBERTS, M.C., 2006. Comparing Petroleum Fiscal Regime under Oil Price Uncertainty. Resource Policy Journal. 31(5), pp 95-105.

[10] BINDEMANN, K., 1999. Production Sharing Agreements: An Economic Analysis. Oxford Institute of Energy Studies. WPM 25.

[11] BLACK, A.J and DUNDAS, H. R. 1992. Joint Operating Agreements: An International Comparison from Petroleum Law, Journal of Energy, Natural Resources and Environmental Law, Vol.8(1), pp.49-79.

[12] BROCK, H. R., CARNES, M. Z., and JUSTICE, R., 2007. Petroleum Accounting: Principles, Procedures, and Issues. $6^{\text {th }}$ Ed. Texas: Professional Development Institute.

[13] BRACKING, S. 2009. Hiding Conflict over Industry Return: A Stakeholder Analysis of the Extractive Industries Transparency Initiative. University of Manchester. Brooks World Poverty Institute. www.manchester.ac.uk/bwpi

[14] DZIENKOWSKI, J. S. 2000. Concession, Production Sharing, and Participating Agreements for Developing Country's Natural Resources, in Smith, E.E. et al International Petroleum Transactions, $2^{\text {nd }}$ ed. USA: Rocky Mountain Mineral Law Foundation, pp, 393-465.

[15] EBRAHIM, A., 2003. Accountability in Practice: Mechanism for NGOs. World Developments. 31(5).

[16] EIGEN, P. 2007. FIGHTING CORRUPTION IN A GLOBAL ECONOMY: TRANSPARENCY INITIATIVES IN THE OIL AND GAS INDUSTRY. HUSTON JOURNAL OF INTERNATIONAL LAW, 29(2).

[17] FRYNAS, J.G.2005.The false development promise of Corporate Social Responsibility: evidence from multinational oil Companies. International Affairs, 81(3).

[18] GIDADO, M. 1999. "Petroleum Development Contracts with the Multinational Oil firms: The Nigerian Experience” Nigeria: Edlinform Services.

[19] Gray, R., Owen, D. and Adams, C., 1996. Accounting and Accountability: Changes and Challenges in Corporate Social and Environmental Reporting. Prentice Hall, London, UK.

[20] IGBANUGO, H. A., 2011. "Joint Ventures in Sub-Saharan African: A New FCPA Minefield. The African Counsel Newsletter.

[21] ILEDARE, O.O. and KAISER, M. 2006. Profitability of Deepwater Petroleum Leases: Emipirical Evidence from the U.S. Gulf of Mexico Offshore Region. Availablefrom: http://www.onepetro.org/mslib/servlet/onepetropreview?id=SPE116602-MS\&soc=SPE [Accessed 09 June, 2012]

[22] JOHNSTON, D. 2003. International Exploration Economics, Risk, and Contract Analysis. Oklahoma: Penn Well Corporation.

[23] JOHNSTON, D., 1994. "International Petroleum Fiscal System and Production Sharing Contracts”. USA: Penn Well.

[24] JOURDON, P., 2006. Regional Strategies-the case for a Resource Based Spatial Development programme. Presentation at the USAfrica Infrastructure conference, September, 28.

[25] KAISER, M.J and PULSIPHER, A.G. 2004. Fiscal System Analysis: Concessionary and Contractual Systems used in
Offshore Petroleum Arrangements. Louisiana: Centre for Energy Studies.

[26] KING and SPALDING LLP. 2005. An Introduction to Upstream Government petroleum Contracts: Their Evolution and Current Use. Oil Gas and Energy Intelligence. 3 (1), pp. 1-22.

[27] KOLSTAD, I. and WIIG, A. 2009. Is Transparency the Key to Reducing Corruption in Resource-Rich Countries? World Development, 37(3)

[28] MIRANDA, L. J. And MALIK, K. A., 2008. "Sustainable Development and Social Responsibility: Key Factors for Positive Impact of International Petroleum Agreements". International Petroleum Technology Conference, December 3-5, Malaysia.

[29] MUHAMMAD, S. D., 2010. "Finding an Optimal Petroleum Fiscal System/Regime for the Nigerian Oil and Gas Industry. MSc. Thesis Aberdeen Business School, Robert Gordon University.

[30] MUHAMMAD, A., 2010. "The Nigerian Petroleum Industry Bill: An Evaluation of the Effect of Proposed Fiscal Terms on Investment in Upstream Sector”. MSc. Dissertation, Dundee Business School, University of Abertay.

[31] OCHEJE, P. D., 2007. "The Extractive Industries Transparency Initiative (EITI): Voluntary Codes of Conduct, Poverty and Accountability in Africa."

[32] Omorogbe, Y. 2005. Fiscal regimes: Nigerian Extractive Industry transparency Initiative, Civil Society capacity Building Workshop. Available from:

http://www.neiti.org.ng/..../Fiscal\%20Regimes.pdf [Accessed 17 May 2010].

[33] ONAIWU, E. 2007. How do fluctuating oil prices affect government take under Nigerian PSC?

[34] OYEFUSI, A., 2007. Oil-dependence and civil conflict in Nigeria. CSAE WPSI2007-2008.

[35] PONSGIRI, N., 2004. "Partnership in Oil and Gas Production Sharing Contracts. Oil, Gas and Energy Law Intelligence 3 (1) Pp 431-442.

[36] ROBINSON, J.A., TORVIK, R. and VERDIER, T. 2006. Political foundation of the resource curse. Journal of Development Economic, 79.

[37] UMAR, M. B., 2005. "Legal Issues in the Management of Nigeria's Production Sharing Contracts from a Study of the Nigerian National Petroleum Corporation's (National Petroleum Investment Management Services) Perspective. Oil, Gas and Energy Law Intelligence. 3(1) Pp 1-120.

[38] UNERMAN, J. and O "DWYER, B. 2006. Theorizing accountability for NGO advocacy. Accounting, Auditing and Accountability Journal, 19(3).

[39] WRIGHT, J.C and GALLUN, R.A. 2005. International petroleum accounting. USA: Pennwell Corporation.

[40] Yumiseva, H (2005) Can Production Sharing Contract Promote Transparency in Management of Oil and Gas Income? A Case Study of Equatorial Guinea. Oil, Gas and Energy Law Intelligence Vol. 3 issue 1. 